\title{
速度変化する飛翔体の改良型比例航法の修正*1 Modification of Augmented Proportional Navigation for a Missile with Varying Velocity
}

\author{
土 肥 直 人 $^{* 2} \cdot$ 馬 場 順 昭*2 $\cdot$ 高 野 博 行*2 \\ Naoto Dohi, Yoriaki BABA and Hiroyuki TAKano
}

Key Words : Guidance and Control, Augmented Proportional Navigation, Target Maneuver

\begin{abstract}
This paper presents a new guidance law for a missile with varying velocity against a maneuvering target with a constant acceleration. Since an approximate missile velocity change during boost phase or after thrust cutoff can be calculated, the intercept point can be estimated if the target acceleration is measured. The guidance law presented guides the missile to the point directly. The guidance law is constructed by combining augmented proportional navigation and pure pursuit navigation with some mixture ratio. From some simulations, it is found that the guidance law presented is more effective and has the higher off-boresight ability and the smaller lateral divert requirements than conventional augmented proportional navigation or proportional navigation even if there exist the LOS angle noises.
\end{abstract}

1. 序

論

目標の加速度情報を利用した飛翔体誘導法としてよく知 られている改良型比例航法は最適誘導法の 1 つである . こ れは, 飛翔体も目標も質点で与え, ともに速度は一定で, か つ, 誘導システムに動的遅れがなく, また目標は一定加速 度で回避運動をするという条件下で, 初期 LOS (Line-OfSight）に対して線形化した直交方向の軌道について誘導加 速度の 2 乗積分値を最小にしながら完全に衝突させるとい う最適制御問題を解くことによって導くことができる ${ }^{1)}$.こ の理論上の結果は極めて有用であるが, 問題設定上の仮定 が崩れると「最適解」が必ずしも最適になるとは限らない． たとえば，今度らは実際に近い飛翔体モデルを用いた会合 シミュレーションによって, 会合面内で回避運動する目標 に対しては目標の回避加速度を考慮した最適解である改良 型比例航法より回避加速度を考慮していない比例航法の方 が有利な場合があることを示している2).さらに，最近では Shinar らが上記のような簡単なモデルに対して最適制御理 論を適用して得た比例航法, 改良型比例航法, 最適誘導法, 微分ゲーム解などか現実的な 3 次元空間での会合問題にど の程度有効であるか , どの仮定が適切でないかなどについ て再突入物体に対する会合シミュレーションで検討を行い， 谷の結果を示している3,4).これによると初期 LOS に関す る軌道の線形化は適切であるが, 飛翔体の速度変化がある 場合には一定速度の仮定は有効ではないとしている．

ところで, 著者らはブースト中とバーンアウト後におい

\footnotetext{
*1 (C) 2004 日本航空宇宙学会

平成 15 年 4 月 9 日，第 34 期日本航空宇宙学会年会講演会にお いて発表. 平成 15 年 12 月 5 日原稿受理

*2 防衛大学校システム工学群航空宇宙学科
}

て飛翔体速度が大きく変化することに着目し，この速度変 化が速度一定の下での最適解である比例航法の有効性を大 きく低下させているので, この速度変化を考慮した誘導法 を提案した ${ }^{5,6)}$. 提案した誘導法の基本的考え方は, ブース ト中とバーンアウト後においては飛翔体に働く加減速度は ほほ推定できるので, これらを考慮して未来会合点を計算 し，飛翔体を光の点へ誘導しようとするものである．この 誘導法は従来の比例航法を修正した形になっており，一定 速度で移動する目標に対して高いオフボアサイト能力を持 つことが示された .

そこで，本論文では前論文と同樣の考え方を一定加速度 で回避運動する目標に適用して, ブースト中とバーンアウ 卜後における誘導法を導く.すなわち, 飛翔体の大きな速 度変化を考慮したとき改良型比例航法はどのように修正す べきかを示す．

$$
\text { 主な 記 号 }
$$

$a_{\mathrm{M}}$ ： 修正改良型比例航法の設計パラメータ

$$
\text { (ブースト中) }
$$

$\vec{a}_{\mathrm{Tn}}$ : 目標の横加速度ベクトル, $a_{\mathrm{Tn}}=\left|\vec{a}_{\mathrm{Tn}}\right|$

$\vec{a}_{\mathrm{Tt}}$ ：目標の接線加速度ベクトル, $a_{\mathrm{Tt}}=\left|\vec{a}_{\mathrm{Tt}}\right|$

$C:$ 横力

$C_{(~)}$ : 空力係数

$D$ : 抗力

$\vec{F}_{(~)}$ ：指令誘導横加速度ベクトル, $F_{(~)}=\left|\vec{F}_{(~)}\right|$

$g:$ 重力加速度

$I_{\mathrm{SP}}$ : 比推力

$k_{(~)}$ : 修正改良型比例航法の合成比

$L$ : 揚力 


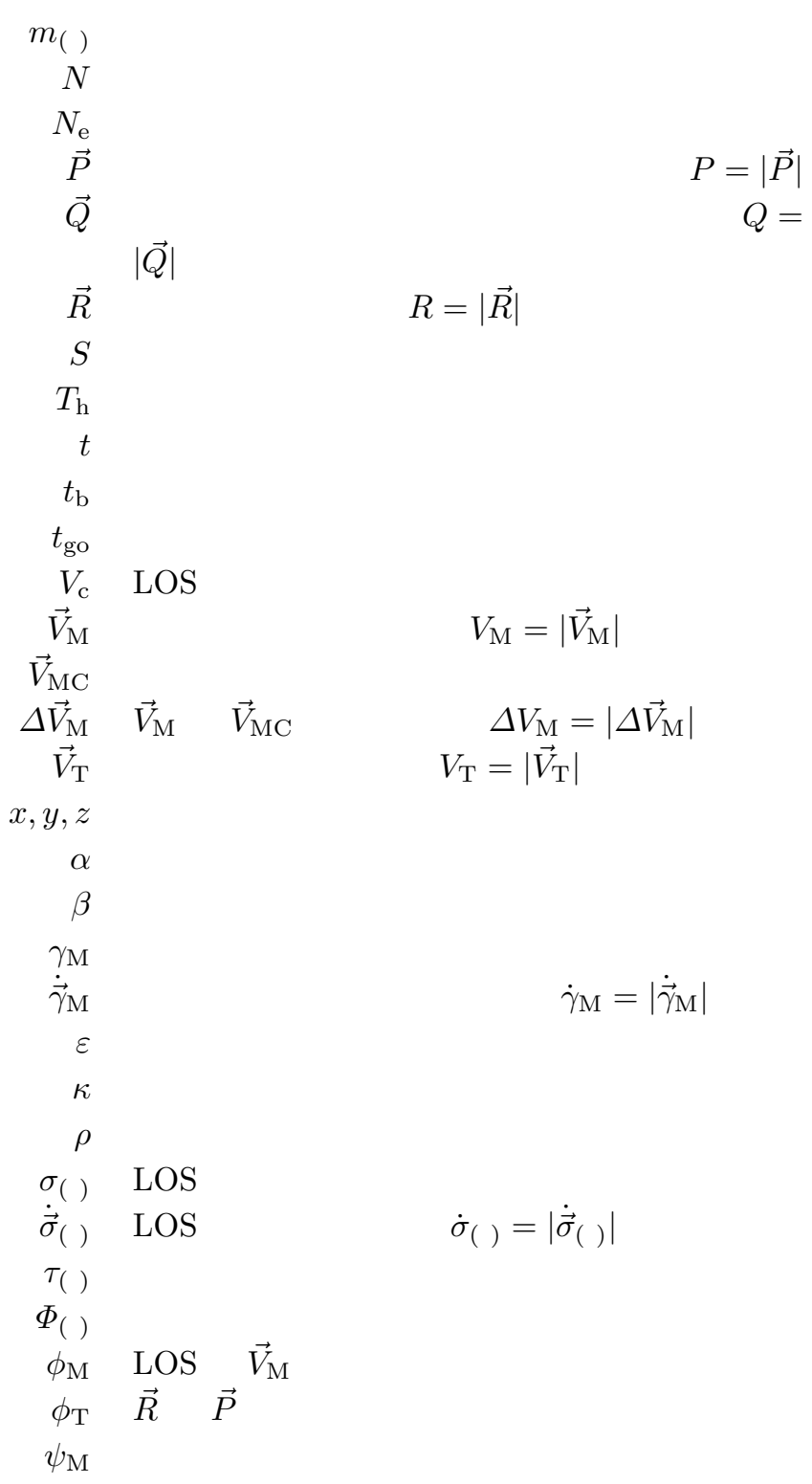

\section{2. 誘導法の構成}

2.1 誘導法の基礎方程式 飛翔体と目標の幾何学的位 置関係を第 1 図に示す.第 1 図において M , T , I を光れ光 れ飛翔体と目標の現在位置及び未来会合位置とすると，三 角形 MTI は会合三角形, 直線 MI は会合経路, 直線 MT は LOS (目視線) となる .ここで, 飛翔体は加速運動ある いは減速運動するものとし, また, 目標は一定加速度で加 速旋回するものとする. 本論文で用いる誘導法の原理は前

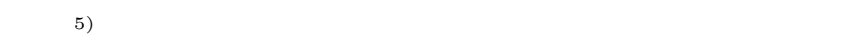
に沿う飛翔体の速度ベクトルを $\vec{V}_{\mathrm{MC}}$ とし, 弚のベクトル から実際の速度ベクトル $\vec{V}_{\mathrm{M}}$ までの偏差を $\Delta \vec{V}_{\mathrm{M}}$ とした場 合, LOSレートベクトル $\dot{\vec{\sigma}}_{M}$ は次式で与えられる .

$$
\dot{\vec{\sigma}}_{\mathrm{M}}=\frac{\vec{R} \times\left(\vec{V}_{\mathrm{T}}-\vec{V}_{\mathrm{MC}}\right)}{R^{2}}+\frac{\vec{R} \times\left(-\Delta \vec{V}_{\mathrm{M}}\right)}{R^{2}}
$$

ここで， $\vec{V}_{\mathrm{T}}$ は目標の速度べクトル， $\vec{R}$ は相対位置べクト ルである. 飛翔体の経路角速度ベクトル $\dot{\vec{\gamma}}_{\mathrm{M}}$ が速度偏差べ クトル $\Delta \vec{V}_{\mathrm{M}}$ によって生じる LOSレートに比例するよう

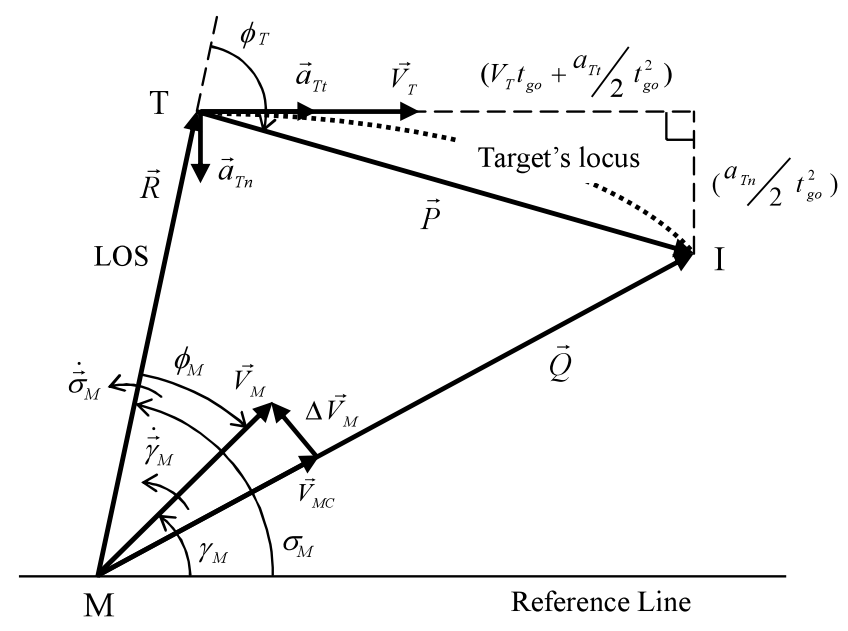

第 1 図 飛翔体と目標との幾何学的関係

に誘導すれば, 航法定数 $N$ を用いて次式が成立する.

$$
\dot{\vec{\gamma}}_{\mathrm{M}}=N \frac{\vec{R} \times\left(-\Delta \vec{V}_{\mathrm{M}}\right)}{R^{2}}
$$

なお, 航法定数 $N$ と有効航法定数 $N_{\mathrm{e}}$ との間には次の関 係があるものとする .

$$
N=\frac{N_{\mathrm{e}} V_{\mathrm{c}}}{V_{\mathrm{M}} \cos \phi_{\mathrm{M}}}
$$

ただし， $V_{\mathrm{c}}$ は飛翔体と目標の接近速度, $\phi_{\mathrm{M}}$ は LOS と速 度ベクトル $\vec{V}_{\mathrm{M}}$ のなす角である. 飛翔体が (2) 式の経路角 速度で旋回するために必要な横加速度べクトル $\vec{F}$ は次式 となる .

$$
\vec{F}=\frac{N}{R^{2}}\left\{\left(\vec{V}_{\mathrm{M}}-\frac{V_{\mathrm{M}}}{Q} \vec{P}\right) \times \vec{R}\right\} \times \vec{V}_{\mathrm{M}}
$$

(4) 式が飛翔体を会合経路上へ誘導するための基礎方程式 であり，計算する上で， $\vec{R}, \vec{V}_{\mathrm{M}}, \vec{P}, Q$ の值が必要となる. $\vec{R}, \vec{V}_{\mathrm{M}}$ は測定可能であるが, 目標の未来位置 $\vec{P}$ と飛翔体 の飛行距離 $Q$ は推定する必要があり次節で述べる．また， 三角形 MTI は会合三角形なので, 各辺 $P, Q, R$ につい て次式が成立する.

$$
Q^{2}-P^{2}-R^{2}-2 P R \cos \phi_{\mathrm{T}}=0
$$

ここで, $\phi_{\mathrm{T}}$ は $\vec{R}$ と $\vec{P}$ のなす角を表し, (5) 式は会合まで の時間 $t_{\mathrm{go}}$ を計算するための方程式となる .

2.2 目標の未来位置 $\overrightarrow{\boldsymbol{P}}$ の推定 目標が加速旋回する場 合, 兴の未来位置を正確に求める式の導出は容易ではない が, 第 1 図に示すように, 目標の進行方向の加速度 $a_{\mathrm{Tt}}$ と 法線加速度 $a_{\mathrm{Tn}}$ が一定で, かつ, 常に同じ方向に働くと仮 定すれば, $t_{\mathrm{go}}$ 後の目標の位置ベクトル $\vec{P}$ は次式で与える ことができる .

$$
\vec{P}=\left(V_{\mathrm{T}}+\frac{a_{\mathrm{Tt}}}{2} t_{\mathrm{go}}\right) t_{\mathrm{go}} \frac{\vec{V}_{\mathrm{T}}}{V_{\mathrm{T}}}+\frac{t_{\mathrm{go}}^{2}}{2} \vec{a}_{\mathrm{Tn}}
$$


2.3 飛翔体の飛行距離 $Q$ の推定 飛翔体の大きな速度 変化はブースト中の加速期間かまたはバーンアウト後の減 速期間である . これらの各期間中における飛行距離の推定 式は文献 5),6) を参考にすると次のようになる.

2.3.1 ブースト中の飛行距離 $\boldsymbol{Q}$ ブースト中において飛 翔体に加わる主な外力は推力, 抗力及び重力であるが, 重 力の影響を無視すると運動方程式は次式となる．

$$
m_{\mathrm{M}} \dot{V}_{\mathrm{M}}=T_{\mathrm{h}}-m_{\mathrm{M}} a_{\mathrm{M}}
$$

ここで， $T_{\mathrm{h}}$ は推力， $m_{\mathrm{M}}$ は飛翔体の質量， $a_{\mathrm{M}}$ は主に空気 抵抗による減速度を表している． $a_{\mathrm{M}}$ を一定と仮定し，(7) 式の両辺を 2 回積分すると, ブースト中の飛翔体の $t_{\mathrm{go}}$ 間 の飛行距離 $Q$ が求まる5 ${ }^{5}$.

$$
\begin{aligned}
Q= & V_{\mathrm{M}}(t) t_{\mathrm{go}}-\frac{a_{\mathrm{M}}}{2} t_{\mathrm{go}}^{2} \\
& +I_{\mathrm{SP}} g t_{\mathrm{go}}\left\{1-\frac{t_{\mathrm{R}}(t)-t_{\mathrm{go}}}{t_{\mathrm{go}}} \log \left(\frac{t_{\mathrm{R}}(t)}{t_{\mathrm{R}}(t)-t_{\mathrm{go}}}\right)\right\}
\end{aligned}
$$

ただし,$g$ は重力加速度， $I_{\mathrm{SP}}$ は比推力である.$t_{\mathrm{R}}(t)$ は飛 翔体の初期質量 $m_{\mathrm{M} 0}$ を用いて次式で表される.

$$
\begin{aligned}
& I_{\mathrm{SP}}=-\frac{T_{\mathrm{h}}}{\dot{m}_{\mathrm{M}} g} \\
& t_{\mathrm{R}}(t)=\frac{I_{\mathrm{SP}} m_{\mathrm{M}} g}{T_{\mathrm{h}}}=\frac{I_{\mathrm{SP}} m_{\mathrm{M} 0} g}{T_{\mathrm{h}}}-t
\end{aligned}
$$

2.3.2 バーンアウト後の飛行距離 $Q$ バーンアウト後に おいても, 重力の影響を無視して飛翔体に加わる主な外力 は空気抵抗のみと考えると運動方程式は次式となる .

$$
\dot{V}_{\mathrm{M}}=-\lambda V_{\mathrm{M}}^{2}
$$

こニで，

$$
\lambda=\frac{\rho S C_{\mathrm{D}}}{2 m_{\mathrm{Mtb}}}
$$

ただし， $\rho$ は空気密度， $S$ は基準面積, $m_{\mathrm{Mtb}}$ はバーンア ウト後の飛翔体の質量， $C_{\mathrm{D}}$ は飛翔体の抗力係数である. $\lambda$ を一定と仮定して，(11) 式を 2 回積分すると，バーンアウ 卜後の飛翔体の $t_{\mathrm{go}}$ 間の飛行距離 $Q$ が求まる ${ }^{6)}$.

$$
Q=\frac{1}{\lambda} \log \left(1+\lambda V_{\mathrm{M}}(t) t_{\mathrm{go}}\right)
$$

2.4 誘導法の構成 目標と飛翔体の $t_{\mathrm{go}}$ 間の $\vec{P}$ と $Q$ の式が得られたので, これらを(4) 式へ代入すれば, 飛翔 体の誘導加速度が求められる. 実際の手順は次のようにな る.まず，(6) 式の $\vec{P}$ とブースト中ならば (8) 式の $Q$ ，ま たはバーンアウト後ならば (13) 式の $Q$ を (5) 式へ代入す ると， $t_{\mathrm{go}}$ に関する超越方程式となり，二れを解いて $t_{\mathrm{go}}$ を 得る.次に，得られた $t_{\mathrm{go}}$ を(6) 式，(8) 式あるいは (13) 式へ代入すると $\vec{P}$ と $Q$ の值が定まるので, これらを (4) 式へ代入すれば, 必要な誘導加速度が得られる．
ところで，一般に飛翔体はシーカでLOSレートを測定 し, 誘導信号として利用するので, (4) 式をこのLOSレー 卜を用いた形に変形する必要がある.(6) 式を (4) 式へ代入 し , パラメータ $k_{0} を$

$$
k_{0}=\frac{V_{\mathrm{M}} t_{\mathrm{go}}}{Q}
$$

と定義すると，(4) 式は次のように変形される .

$$
\begin{aligned}
\vec{F}= & N k_{1} \frac{\left(\vec{V}_{\mathrm{M}}-\vec{V}_{\mathrm{T}}\right) \times \vec{R}}{R^{2}} \times \vec{V}_{\mathrm{M}} \\
& +N\left(1-k_{1}\right) \frac{\vec{V}_{\mathrm{M}} \times \vec{R}}{R^{2}} \times \vec{V}_{\mathrm{M}} \\
& +N k_{2} \frac{\vec{R} \times \vec{a}_{\mathrm{Tn}}}{R^{2}} \times \vec{V}_{\mathrm{M}}
\end{aligned}
$$

ただし， $k_{1} ， k_{2}$ は $k_{0}$ を用いて次式で定義した .

$$
\begin{aligned}
& k_{1}=k_{0}\left(1+\frac{a_{\mathrm{Tt}}}{2 V_{\mathrm{T}}} t_{\mathrm{go}}\right) \\
& k_{2}=k_{0} \frac{t_{\mathrm{go}}}{2}
\end{aligned}
$$

(15) 式の第 1 項は航法定数を $N k_{1}$ とする比例航法であり， 第 2 項は航法ゲインを $N\left(1-k_{1}\right)$ とする単純追尾航法を 表し，第 3 項は目標の回避運動に対する補正項であり航法 ゲインは $N k_{2}$ である. 飛翔体と目標が同一の会合面内で 運動している場合には第 1 項と第 2 項はこの会合面内での 誘導加速度を表している．また，第 3 項の加速度は目標の 回避加速度 $\vec{a}_{\mathrm{Tn}}$ の方向で決まる. $\vec{a}_{\mathrm{Tn}}$ が飛翔体や目標と 同じ会合面内にあれば，第 3 項の加速度も同一の会合面内 にあるが，目標が会合面外へ回避すれば，第 3 項は会合面 に対して垂直方向への誘導加速度を与える．ところで, 飛 翔体速度が一定の場合 $Q=V_{\mathrm{M}} t_{\mathrm{go}}$ なので $k_{0}=1$ とな り, さらに, 目標は速度一定 $\left(a_{\mathrm{Tt}}=0\right)$ で, 回避運動のみ をする場合には $k_{1}=1, k_{2}=t_{\mathrm{go}} / 2$ となり，(15) 式は従 来の改良型比例航法とまったく同じ形になる .このことか らも明らかなように，(15) 式で与えられる誘導法は従来の 改良型比例航法を飛翔体と目標の速度が変化する場合にも 適用できるように修正したものであり，本論文では便宜上， 修正改良型比例航法 (Modified Augmented Proportional Navigation; MAPN と略記) と呼ぶことにする.また， $k_{1}$ は比例航法と単純追尾航法の合成の割合を， $k_{2}$ は目標の回 避運動に対する補正項の割合を決めているので, 各誘導法 の合成比を示している．乥こで， $k_{1} ， k_{2}$ を合成比と呼ぶこ とにする . 2 次元の場合について修正改良型比例航法の構 成を第 2 図に示す．ただし，この図にはノイズを含んだシ ミュレーションのためのブロック图も示してある. 第 2 図 から修正改良型比例航法は改良型比例航法と単純追尾航法 を合成したもので, 合成比 $k_{1}, k_{2}$ が合成の割合を決定す る重要なパラメータとなることがわかる．なお，第 2 图の $A_{\mathrm{T}}$ は目標の横加速度の LOS に垂直な成分であり, ベクト ルで表示すると次式となる．

$$
\vec{A}_{\mathrm{T}}=\frac{\vec{R} \times \vec{a}_{\mathrm{Tn}}}{R}
$$




\section{3. 合成比と設計パラメータとの関係}

(15) 式または第 2 図から明らかなように修正改良型比例航 法の誘導性能は合成比 $k_{1}, k_{2}$ によって決まる . (16)，(17) 式から $k_{1}, k_{2}$ は $k_{0}$ の関数なので, 修正改良型比例航法 の設計はパラメータ $k_{0}$ をどのように決めるかという問題
になる．乥こで，ブースト中とバーンアウト後の場合に分 けて $k_{0}$ の決定法を示す .

3.1 ブースト中の合成比 パラメータ $k_{0}$ の定義式 (14) にブースト中の飛翔体の飛行距離 $Q$ を表す $(8)$ 式を代入す ると次式を得る .

$$
k_{0}=\frac{V_{\mathrm{M}} t_{\mathrm{go}}\left(a_{\mathrm{M}}\right)}{V_{\mathrm{M}} t_{\mathrm{go}}\left(a_{\mathrm{M}}\right)-\frac{a_{\mathrm{M}}}{2} t_{\mathrm{go}}\left(a_{\mathrm{M}}\right)^{2}+I_{\mathrm{SP}} g t_{\mathrm{go}}\left(a_{\mathrm{M}}\right)\left\{1-\frac{t_{\mathrm{R}}-t_{\mathrm{go}}\left(a_{\mathrm{M}}\right)}{t_{\mathrm{go}}\left(a_{\mathrm{M}}\right)} \log \left(\frac{t_{\mathrm{R}}}{t_{\mathrm{R}}-t_{\mathrm{go}}\left(a_{\mathrm{M}}\right)}\right)\right\}}
$$

ここで, $t_{\mathrm{go}}$ は $a_{\mathrm{M}}$ の関数であることを明示するために $t_{\mathrm{go}}\left(a_{\mathrm{M}}\right)$ とした . $a_{\mathrm{M}}$ は空気抵抗による減速度の平均值を 表しているが, 飛翔体誘導の立場から考えれば, 修正改良 型比例航法を決定する重要なパラメータである. 何故なら， $a_{\mathrm{M}}$ を与えれば，(19) 式から $k_{0}$ が定まり，(16)，(17) 式か ら合成比 $k_{1}, k_{2}$ が決まるからである. 乥こで, 発射時の高 度, 速度, オフボアサイト角などに応じてミスディスタン スが零となるように $a_{\mathrm{M}}$ を決めることにする .このような $a_{\mathrm{M}}$ を解析的に求めることは困難なのでシミュレーションに よって決める．実際の計算は次のように行う，飛翔体の発射 位置と発射速度を定めて, オフボアサイト角ごとに $a_{\mathrm{M}}$ を 変化させながら会合シミュレーションを行い, ミスディス タンスを求める .これらの結果を第 3 図に示すように横軸 をオフボアサイト角 $\varepsilon$, 縦軸を設計パラメータ $a_{\mathrm{M}}$ とする グラフ上に記録し，この平面上でミスディスタンス (MD) がある値となるような等高線を描く.第 3 図は $\mathrm{MD}=0 \mathrm{~m}$ と $\mathrm{MD}=1 \mathrm{~m}$ となるような典型的な模擬の等高線図を示し たものである.この図に示したように，一般に $\mathrm{MD}=0 \mathrm{~m}$ の等高線を中心に, MD が大きくなるような等高線が両側 に広がっている . 第 3 図から次のようなことがわかる .

(i) ある $\varepsilon_{1}$ に対し, $\mathrm{MD}=0 \mathrm{~m}$ となる $a_{\mathrm{M}}$ は $a_{\mathrm{M} 1}$ と $a_{\mathrm{M} 2}$ の 2 つが存在している .これらの值のどちらを選択すべ きかを数学的に決めるには別の評価関数が必要であるが，

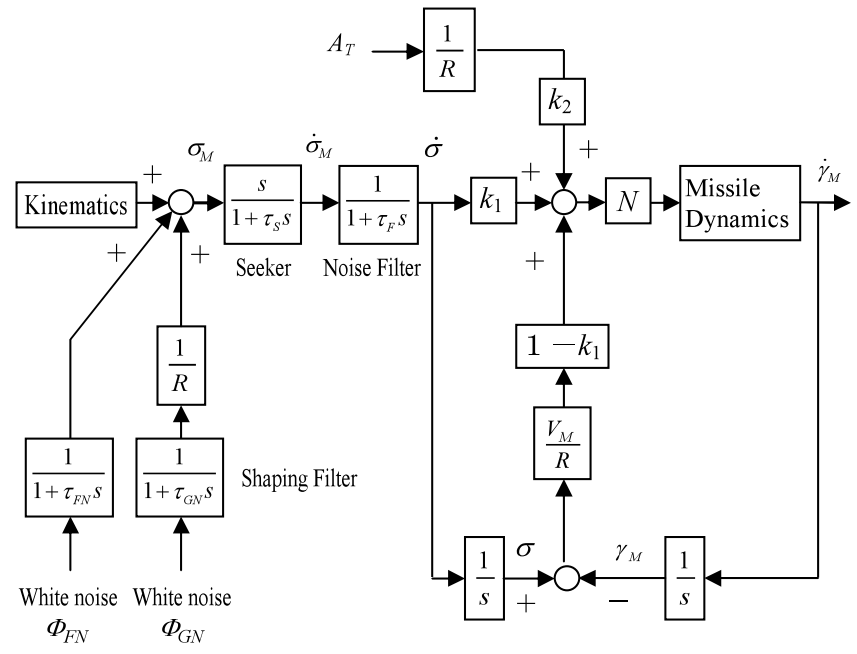

第 2 図 修正改良型比例航法の構成
物理的にはなるべく真の減速度の平均值に近い值を選ぶ 方がよい．なぜなら， $a_{\mathrm{M}}$ が真の減速度の平均值に近い ほど無理な運動をすることなしに, 未来会合点に向かっ て直線に近い軌道をとるからである．

(ii) $a_{\mathrm{M}}$ が負の值に設定されると加速度とみなされる . 実 際には減速度が働いているにもかかわらず， $a_{\mathrm{M}}$ を加速 度とみなすことによって飛翔体はミスディスタンスが小 さくなるような軌道を選択することになる．

(iii) 一般に $a_{\mathrm{M}}$ には上限と下限が存在する .なぜなら， $a_{\mathrm{M}}$ が正に大きすぎると減速度が大きすぎることになり，逆 に $a_{\mathrm{M}}$ が負に大きすぎると加速度が大きすぎて，いずれ の場合も会合三角形が存在しなくなるからである .

(iv) $a_{\mathrm{M}}=a_{\mathrm{M} 2}$ は広いオフボアサイト角に対して有効なパ ラメータである.なぜなら，広い範囲の $\varepsilon$ に対し MD $\fallingdotseq 0$ となっているからである

(v) 等高線間の幅が広いほど, $\varepsilon や a_{\mathrm{M}}$ の変動に対してミ スディスタンスのロバスト性が高い，逆に，幅が狭くな るほどロバスト性は低くなる .

(vi) あらゆる $\varepsilon$ に対して $\mathrm{MD}=0 \mathrm{~m}$ となる $a_{\mathrm{M}}$ が存在する とは限らない $. \varepsilon<\varepsilon_{0}$ に対しては $\mathrm{MD}=0 \mathrm{~m}$ とはなら ないので, このようなオフボアサイト角に対しては MD ができるだけ小さくなるような $a_{\mathrm{M}}$ を選ぶ .

会合問題が平面内に限られている場合には飛翔体の発射 条件に応じて $a_{\mathrm{M}}$ を 1 つ決めればよいので, 第 3 図のよう な図を 1 つ求めればよい. しかし, 目標が会合面外への回 避運動を行う場合には, 面外運動について同樣の図を求め

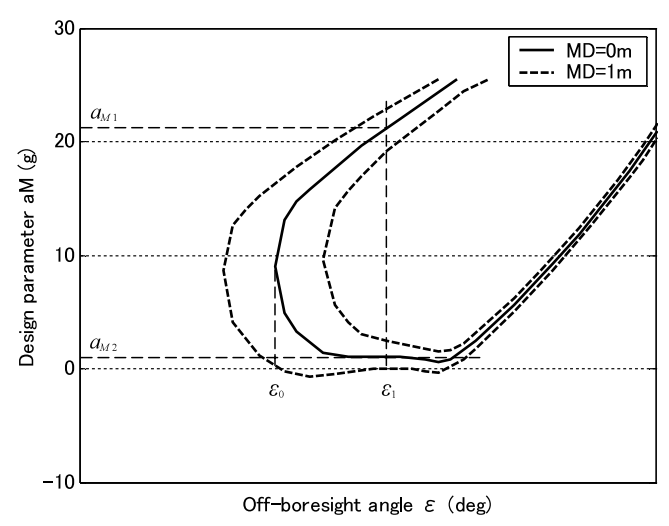

第 3 図 $\varepsilon-a_{\mathrm{M}}$ 平面上のミスディスタンスの等高線 
る必要がある.詳細は後のシミュレーションにて示す．

3.2 バーンアウト後の合成比 バーンアウト後では, 修 正改良型比例航法のパラメータ $k_{0}$ の式 (14) (12), (13) 式を代入すると， $k_{0}$ は抗力係数 $C_{\mathrm{D}}$ の関数であることがわ かる.すなわち，バーンアウト後の修正改良型比例航法を 決定するパラメータは $C_{\mathrm{D}}$ であるので, ブースト中の $a_{\mathrm{M}}$ と同樣にして, ロケットモータ燃焼直後の高度, 速度, オフ ボアサイト角に応じてミスディスタンスが零となるように $C_{\mathrm{D}}$ を決めればよい. 実際の決定法は $a_{\mathrm{M}}$ が $C_{\mathrm{D}}$ に変わっ たことを除けば , ブースト中の場合とまったく同じである . また, $\varepsilon-C_{\mathrm{D}}$ 平面上のミスディスタンスの等高線も第 3 図 と同樣の性質を持っている.

\section{4. 会合シミュレーション}

前節で提案した誘導法の有効性を検討するために短射程 の飛翔体に適用して, 平面及び 3 次元空間における会合シ ミュレーションを行う. 比較のために比例航法, 改良型比 例航法についても同樣の計算を行う. 飛翔体も目標も質点 とし，座標系及び記号を第 4 図のように設定する。飛翔体 はスキッド・ツー・ターンするものと仮定すれば, 運動方 程式は次式で与えられる．

$$
\begin{aligned}
& \dot{x}_{\mathrm{M}}=V_{\mathrm{M}} \cos \gamma_{\mathrm{M}} \cos \psi_{\mathrm{M}} \\
& \dot{y}_{\mathrm{M}}=V_{\mathrm{M}} \cos \gamma_{\mathrm{M}} \sin \psi_{\mathrm{M}} \\
& \dot{z}_{\mathrm{M}}=-V_{\mathrm{M}} \sin \gamma_{\mathrm{M}} \\
& m_{\mathrm{M}} \dot{V}_{\mathrm{M}}=T_{\mathrm{h}} \cos \alpha \cos \beta-D \\
& m_{\mathrm{M}} V_{\mathrm{M}} \dot{\gamma}_{\mathrm{M}}=T_{\mathrm{h}} \sin \alpha+L \\
& m_{\mathrm{M}} V_{\mathrm{M}} \cos \gamma_{\mathrm{M}} \dot{\psi}_{\mathrm{M}}=-T_{\mathrm{h}} \cos \alpha \sin \beta-C \\
& \dot{\alpha}=-\frac{1}{\tau_{\alpha}} \alpha+\frac{1}{\tau_{\alpha}} \alpha_{\mathrm{c}} \\
& \dot{\beta}=-\frac{1}{\tau_{\beta}} \beta+\frac{1}{\tau_{\beta}} \beta_{\mathrm{c}}
\end{aligned}
$$
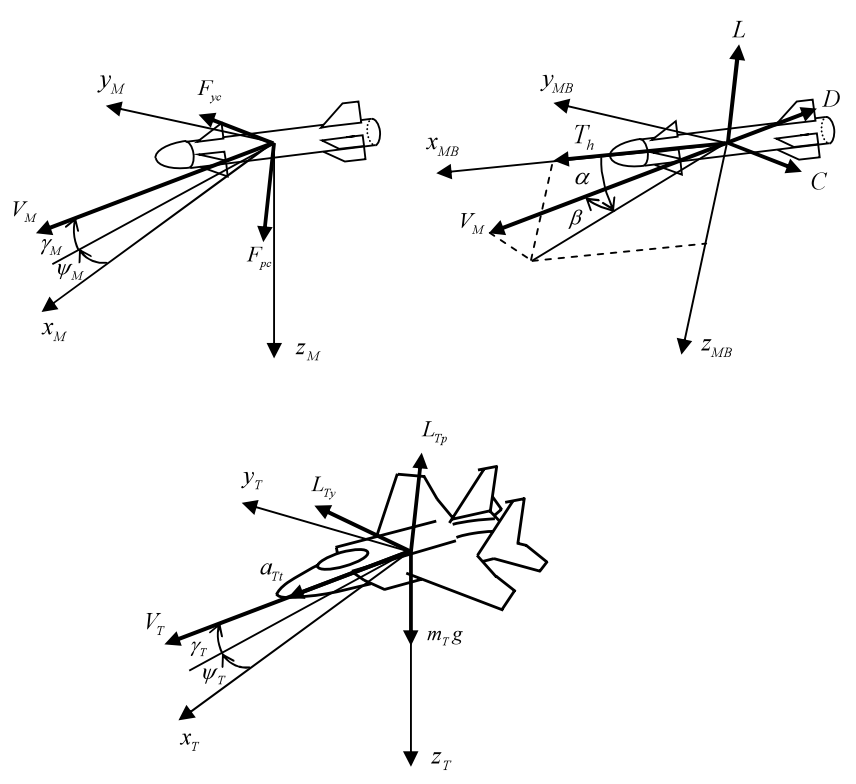

第 4 図 座標系と記号

$$
\begin{aligned}
& m_{\mathrm{M}}=m_{\mathrm{M} 0}-\frac{T_{\mathrm{h}}}{I_{\mathrm{SP}} g} t \\
& L=0.5 \rho V_{\mathrm{M}}^{2} S C_{\mathrm{L} \alpha} \alpha \\
& C=0.5 \rho V_{\mathrm{M}}^{2} S C_{\mathrm{L} \alpha}(-\beta) \\
& D=0.5 \rho V_{\mathrm{M}}^{2} S\left\{C_{\mathrm{D} 0}+\kappa\left(C_{\mathrm{L} \alpha}^{2} \alpha^{2}+C_{\mathrm{L} \alpha}^{2} \beta^{2}\right)\right\} \\
& \alpha_{\mathrm{c}}=\frac{-m_{\mathrm{M}} F_{\mathrm{pc}}}{0.5 \rho V_{\mathrm{M}}^{2} S C_{\mathrm{L} \alpha}} \\
& \beta_{\mathrm{c}}=\frac{m_{\mathrm{M}} F_{\mathrm{yc}}}{0.5 \rho V_{\mathrm{M}}^{2} S C_{\mathrm{L} \alpha}}
\end{aligned}
$$

$F_{\mathrm{pc}}, F_{\mathrm{yc}}$ はピッチ方向及びヨー方向の指令誘導加速度であ り，前節で述べた誘導則から与えられる．これらの式はほ ぼ同じ形なのでヨー方向の指令誘導加速度のみを示す. 修 正改良型比例航法の場合は，ヨ一方向の合成比を $k_{1 \mathrm{y}}, k_{2 \mathrm{y}}$ とすると次式となる .

$$
\begin{aligned}
F_{\mathrm{yc}}= & N k_{1 \mathrm{y}} V_{\mathrm{M}} \dot{\sigma}_{\mathrm{y}}+N\left(1-k_{1 \mathrm{y}}\right) V_{\mathrm{M}} \frac{V_{\mathrm{M}} \sin \left(\sigma_{\mathrm{y}}-\psi_{\mathrm{M}}\right)}{R} \\
& +N k_{2 \mathrm{y}} V_{\mathrm{M}} \frac{a_{\text {Tny }} \cos \left(\psi_{\mathrm{T}}-\sigma_{\mathrm{y}}\right)}{R}
\end{aligned}
$$

また，比例航法の場合は次式となる．

$$
F_{\mathrm{yc}}=N V_{\mathrm{M}} \dot{\sigma}_{\mathrm{y}}
$$

改良型比例航法の場合は次式となる .

$$
F_{\mathrm{yc}}=N V_{\mathrm{M}} \dot{\sigma}_{\mathrm{y}}+N V_{\mathrm{M}} \frac{t_{\mathrm{go}}}{2} \frac{a_{\text {Tny }} \cos \left(\psi_{\mathrm{T}}-\sigma_{\mathrm{y}}\right)}{R}
$$

一方, 目標は飛翔体から逃れるために加速旋回するものと し，運動方程式を次式で与える．

$$
\begin{aligned}
& \dot{x}_{\mathrm{T}}=V_{\mathrm{T}} \cos \gamma_{\mathrm{T}} \cos \psi_{\mathrm{T}} \\
& \dot{y}_{\mathrm{T}}=V_{\mathrm{T}} \cos \gamma_{\mathrm{T}} \sin \psi_{\mathrm{T}} \\
& \dot{z}_{\mathrm{T}}=-V_{\mathrm{T}} \sin \gamma_{\mathrm{T}} \\
& \dot{V}_{\mathrm{T}}=a_{\mathrm{Tt}}-g \sin \gamma_{\mathrm{T}} \\
& m_{\mathrm{T}} V_{\mathrm{T}} \dot{\gamma}_{\mathrm{T}}=L_{\mathrm{Tp}}-m_{\mathrm{T}} g \cos \gamma_{\mathrm{T}} \\
& m_{\mathrm{T}} V_{\mathrm{T}} \cos \gamma_{\mathrm{T}} \dot{\psi}_{\mathrm{T}}=L_{\mathrm{Ty}} \\
& L_{\mathrm{Ty}}=a_{\mathrm{Tny}} m_{\mathrm{T}} \\
& L_{\mathrm{Tp}}=a_{\mathrm{Tnp}} m_{\mathrm{T}} \\
& a_{\mathrm{Tn}}^{2}=a_{\mathrm{Tny}}^{2}+a_{\mathrm{Tnp}}^{2}
\end{aligned}
$$

目標は横加速度 $a_{\mathrm{Tny}}, a_{\mathrm{Tnp}}$ を与えることによって旋回運 動する .

以下のすべてのシミュレーションにおいて , 初期高度は 飛翔体も目標も $5000 \mathrm{~m}$ とし, 初期相対位置は第 5 図に示 すように目標に対し飛翔体が真横からオフボアサイト角 $\varepsilon$ で追尾する場合を考える．すなわち，ブースト段階につい ては飛翔体が真横から $\varepsilon$ 角度で発射されるものとし，ま た , バーンアウト後については真横において速度べクトル $\vec{V}_{\mathrm{M}}$ が角度 $\varepsilon$ をなす状態でバーンアウトしたものとする . シ ミュレーションで使用した飛翔体の基準パラメータを第 1 表に示す. 空力係数 $C_{\mathrm{L} \alpha}, C_{\mathrm{D} 0}, \kappa$ はマッハ数の関数であ 


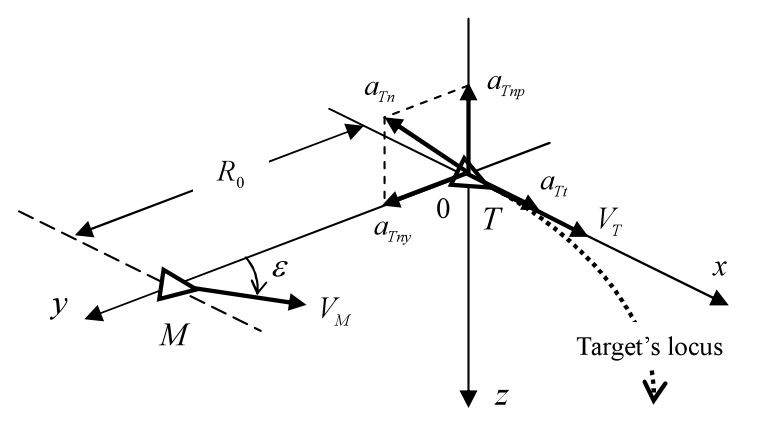

第 5 図飛翔体と目標の初期位置

第 1 表 シミュレーションにおける基準パラメータ

\begin{tabular}{lll}
\hline$m_{\mathrm{M} 0}{ }^{*}=94 \mathrm{~kg}$ & $m_{\mathrm{Mtb}}=63 \mathrm{~kg}$ & $N_{\mathrm{e}}=3.5$ \\
$I_{\mathrm{SP}}{ }^{*}=231 \mathrm{~s}$ & $t_{\mathrm{b}}{ }^{*}=5.5 \mathrm{~s}$ & $\tau_{\alpha, \beta}=0.3 \mathrm{~s}$ \\
$T_{\mathrm{h}}{ }^{*}=12740 \mathrm{~N}$ & $S=0.0127 \mathrm{~m}^{2}$ & $\tau_{\mathrm{S}, \mathrm{F}}=0.05 \mathrm{~s}$ \\
$\Phi_{\mathrm{GN}}=3.15 \times 10^{-7} \mathrm{rad}^{2} / \mathrm{Hz}$ at $1000 \mathrm{~m}$ & $\tau_{\mathrm{GN}}=0.05 \mathrm{~s}$ \\
$\Phi_{\mathrm{FN}}=0.5 \times 10^{-6} \mathrm{rad}^{2} / \mathrm{Hz}$ & \multicolumn{2}{c}{$\tau_{\mathrm{FN}}=0.01 \mathrm{~s}$} \\
荷重制限 $= \pm 30 \mathrm{~g}$ & ブラインド距離 $=100 \mathrm{~m}$ \\
最大迎角/横滑り角 $= \pm 25 \mathrm{deg}$ & ディスエイブル時間* $=0.5 \mathrm{~s}$ \\
\hline *ブースト中のみに使用.
\end{tabular}

り，文献 6) と同じデータを用いた．また，目標は質量を $m_{\mathrm{T}}=15000 \mathrm{~kg}$, 初期マッ八数を $0.75 \mathrm{Mach}$ とし, $x$ 軸正 方向に加速旋回するが，このとき，接線加速度を $a_{\mathrm{Tt}}=1 \mathrm{~g}$ ， 横加速度 $a_{\mathrm{Tn}}, a_{\mathrm{Tnp}}$ については

平面運動の場合

$$
a_{\text {Tn }}=6 \mathrm{~g}, \quad a_{\text {Tnp }}=1 \mathrm{~g}
$$

\section{3 次元運動の場合}

$$
a_{\text {Tny }}=a_{\text {Tnp }}=6 \mathrm{~g}
$$

とした 。

4.1 速度変化が改良型比例航法に与える影響 飛翔体の 速度変化か改良型比例航法に与える影響について調べるた めに，目標が平面内で加速旋回 $\left(a_{\mathrm{Tt}}=1 \mathrm{~g}, a_{\mathrm{Tn}}=6 \mathrm{~g}\right.$ ， $\left.a_{\mathrm{Tnp}}=1 \mathrm{~g}\right)$ する場合のシミュレーションを行った . は じめに, ブースト段階について述べる.飛翔体初期速度 を $0.75 \mathrm{Mach}$ とし，オフボアサイト角を $\varepsilon=24.62^{\circ}$ に 固定し, 初期相対距離 $R_{0}$ を200〜 $3000 \mathrm{~m}$ に変化させた . $\varepsilon=24.62^{\circ}$ は飛翔体速度を $1.8 \mathrm{Mach}$ (これはブースト中の 平均速度) に固定したときの正しいリード角であり, 速度变 化がなければ，ミスディスタンス (MD) はほぼ零となる . シミュレーション結果を第 6 图上段に示す. 横軸は $R_{0}$, 縦 軸はMD である . この図から $R_{0}$ が 200〜 $1500 \mathrm{~m}$ の間では $\mathrm{MD}$ はブースト中の速度変化のために $10 \mathrm{~m}$ 以上となること がわかる.次にバーンアウト後について述べる.飛翔体初期 速度を $2.85 \mathrm{Mach}$ とし，オフボアサイト角を $\varepsilon=15.24^{\circ}$ に 固定し， $R_{0}$ を同樣に変化させた $. \varepsilon=15.24^{\circ}$ は飛翔体速度 を2.85 Mach に固定したときの正しいリード角であり，こ の速度を維持し続ければ MD はほぼ零となる . シミュレー ション結果を第 6 図下段に示す .この図からバーンアウト 後の速度变化も $R_{0}$ が $1500 \mathrm{~m}$ 以下では改良型比例航法に

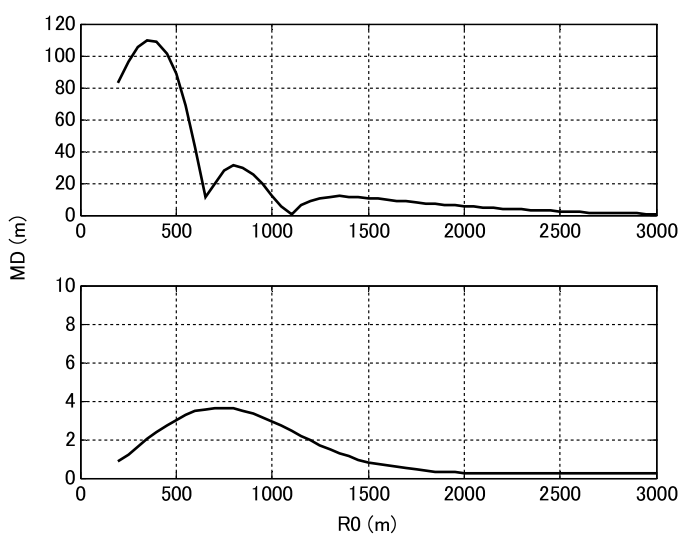

第 6 図 初期相対距離とミスディスタンスとの関係

上段 : ブースト中 , $\varepsilon=24.62^{\circ}$. 下段 : バーンアウト後， $\varepsilon=15.24^{\circ}$.

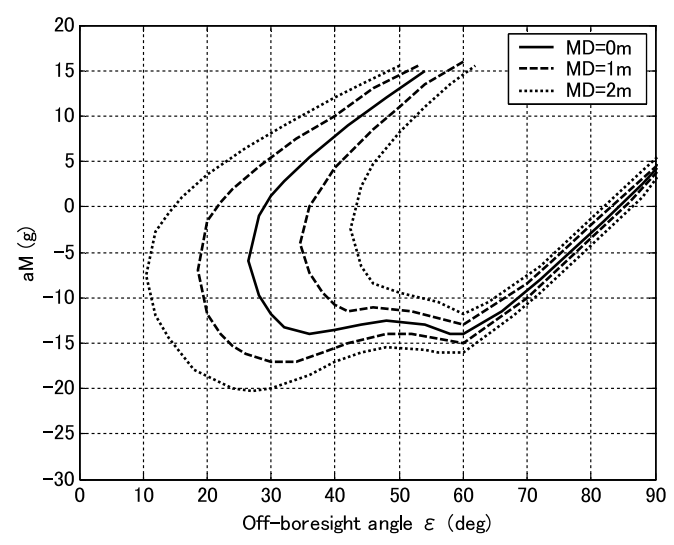

第 7 図 $\varepsilon-a_{\mathrm{M}}$ 平面上のミスディスタンスの等高線 $\left(R_{0}=1500 \mathrm{~m}, 2\right.$ 次元)

影響を与えるが, ブースト中と比較してかなり小さい，光 こで, 以下ではブースト中のみについて述べる .

4.22 次元におけるシミュレーション 飛翔体の発射 位置を $R_{0}=1500 \mathrm{~m}$ とし, 平面内で加速旋回する目標 $\left(a_{\mathrm{Tt}}=1 \mathrm{~g}, a_{\mathrm{Tn}}=6 \mathrm{~g}, a_{\mathrm{Tnp}}=1 \mathrm{~g}\right)$ に対するシミュレー ションを実施した . はじめに,この発射条件における修正 改良型比例航法の設計パラメータ $a_{\mathrm{M}}$ を決めるために $\varepsilon$ と $a_{\mathrm{M}}$ を変化させてシミュレーションを行い, 第 7 图を得た . この図から $26^{\circ}$ 以上のオフボアサイト角に対しては適切な $a_{\mathrm{M}}$ を選べばミスディスタンスを $0 \mathrm{~m}$ にできることがわか る.また，3.1で述べたようにあるオフボアサイト角に対し て $\mathrm{MD}=0 \mathrm{~m}$ となる $a_{\mathrm{M}}$ が 2 つ存在する.例えば, $\varepsilon=32^{\circ}$ のとき， $\mathrm{MD}=0 \mathrm{~m}$ とする $a_{\mathrm{M}}$ は -13.25 と 2.75 である . $a_{\mathrm{M}}$ としてこれらの異なる値を選んだとき, 飛行軌跡, 減速 度, 指令加速度はどのように变化するかを調べた . 飛行経 路を第 8 図, 減速度と指令加速度の時間履歴を第 9 図, 第 10 図に示した .いずれの図にも，比例航法 (PN) 及び改良 型比例航法 (APN) の結果も示した .また，第 2 表には最 接近時の時間 $t_{\mathrm{f}}$, 速度 $V_{\mathrm{M}}\left(t_{\mathrm{f}}\right)$ ， ミスディスタンス $\mathrm{MD}$ を 示した . 第 8 図から PNや APN の経路は大きく曲がって いるが, MAPN の経路はかなり直線に近くなっており，特 


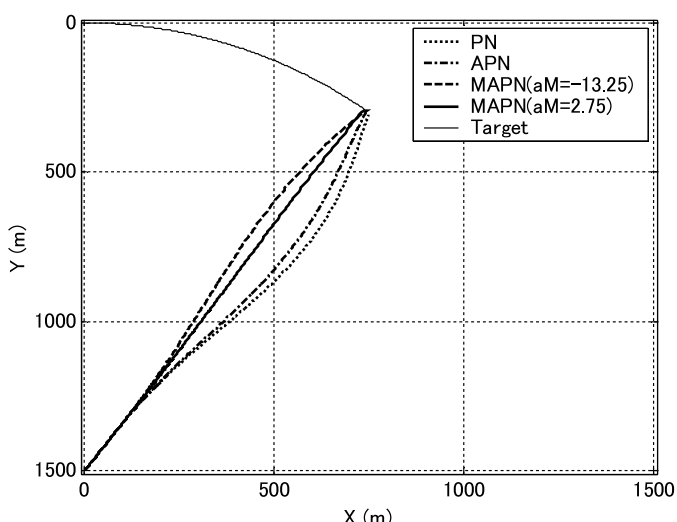

第 8 図 飛翔体と目標の軌跡 $\left(R_{0}=1500 \mathrm{~m}, \varepsilon=32^{\circ}, 2\right.$ 次元 $)$

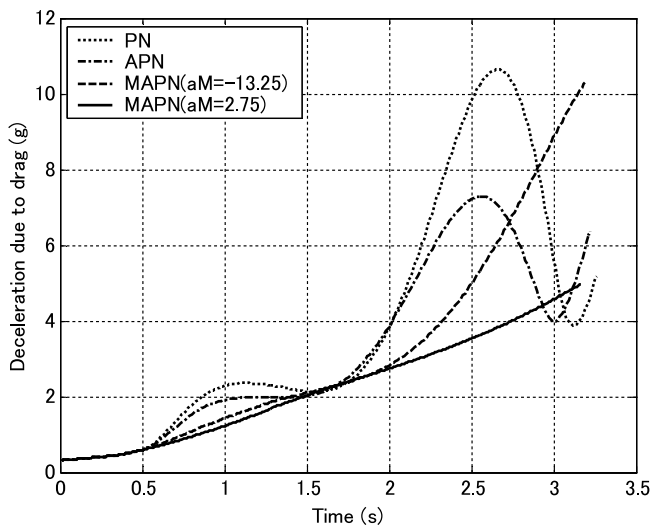

第 9 図 減速度 $D / m$ の時間履歴 $\left(R_{0}=1500 \mathrm{~m}, \varepsilon=32^{\circ}, 2\right.$ 次元 $)$

第 2 表 最接近時の時間, 速度，ミスディスタンス $\left(R_{0}=1500 \mathrm{~m}\right.$ ， $\varepsilon_{0}=32^{\circ}, 2$ 次元 $)$

\begin{tabular}{lccc}
\hline & $t_{\mathrm{f}}(\mathrm{s})$ & $V_{\mathrm{M}}\left(t_{\mathrm{f}}\right)(\mathrm{m} / \mathrm{s})$ & $\mathrm{MD}(\mathrm{m})$ \\
\hline MAPN $\left(a_{\mathrm{M}}=2.75\right)$ & 3.17 & 647.5 & 0.02 \\
MAPN $\left(a_{\mathrm{M}}=-13.75\right)$ & 3.19 & 621.8 & 0.02 \\
APN & 3.22 & 621.8 & 8.28 \\
PN & 3.26 & 602.6 & 8.85 \\
\hline
\end{tabular}

に $a_{\mathrm{M}}=2.75$ の経路はほぼ直線になっていることがわかる . 実際, $a_{\mathrm{M}}=2.75$ は全飛行中の減速度のほぼ平均值に等し いことが第 9 図からわかる . また , 第 10 図からは経路が大 きく曲がっているほど大きな指令加速度を必要としている ことがわかる. 光して, 指令加速度が大きいほど, 誘導抗力 が大きくなるので PN の $V_{\mathrm{M}}\left(t_{\mathrm{f}}\right)$ は $\mathrm{MAPN}\left(a_{\mathrm{M}}=2.75\right)$ の $V_{\mathrm{M}}\left(t_{\mathrm{f}}\right)$ より $45 \mathrm{~m} / \mathrm{s}$ だけ小さくなっている. $\mathrm{PN}$ と $\mathrm{APN}$ は終末に近づくにつれて指令加速度が大きくなっているが， 制限荷重と誘導システムの動的遅れのために MD は $8 \mathrm{~m}$ 以 上になっている.他方, MAPN $\left(a_{\mathrm{M}}=-13.25\right)$ の指令加 速度も終末に近づくにつれて増大しているものの制限荷重 以下であるために MD はほぼ $0 \mathrm{~m}$ となっている .これらの 結果は 3.1 で述べたことを示している.

4.33 次元空間におけるシミュレーション 目標が $1 \mathrm{~g}$ で加速しながら $45^{\circ}$ のバンク角をとり $8.49 \mathrm{~g}$ の加速度で斜 上方へ回避運動 $\left(a_{\mathrm{Tt}}=1 \mathrm{~g}, a_{\mathrm{Tny}}=a_{\mathrm{Tnp}}=6 \mathrm{~g}\right)$ する

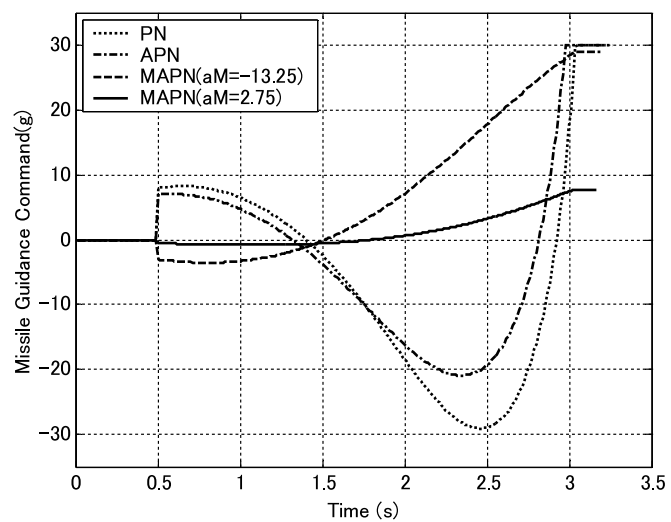

第 10 図 指令加速度の時間履歴 $\left(R_{0}=1500 \mathrm{~m}, \varepsilon=32^{\circ}, 2\right.$ 次元 $)$
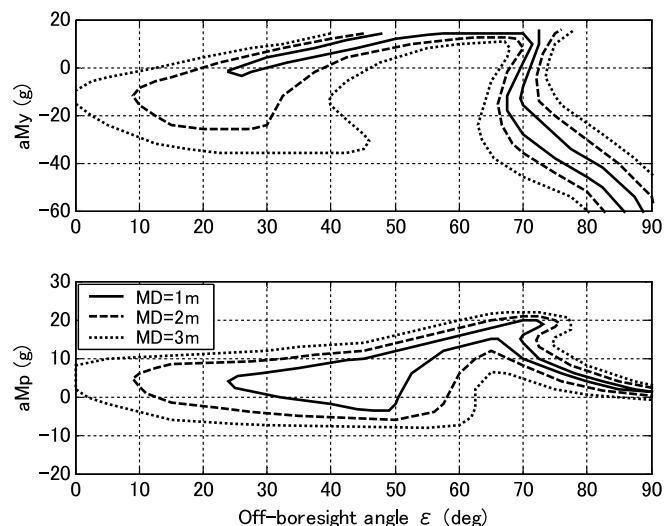

第 11 図 修正改良型比例航法における $\varepsilon-a_{\mathrm{My}}, \varepsilon-a_{\mathrm{Mp}}$ 平面上のミス ディスタンスの等高線 $\left(R_{0}=1500 \mathrm{~m}, 3\right.$ 次元 $)$

場合を考える . 飛翔体の発射位置は 2 次元の場合と同樣に $R_{0}=1500 \mathrm{~m}$ の点とする . 目標運動は 3 次元運動である が , 飛翔体は前述したようにスキッド・ツー・ターンするも のと仮定しているので, 修正改良型比例航法はヨー方向と ピッチ方向に分離して設計する . すなわち , 各々の方向に ついて, $\varepsilon$ と $a_{\mathrm{My}}$ または $\varepsilon と a_{\mathrm{Mp}}$ を変化させながらシミュ レーションを行い第 11 図を得た .この図において, $\mathrm{MD}=$ $0 \mathrm{~m}$ となる等高線は $\mathrm{MD}=1 \mathrm{~m}$ に囲まれる領域内に部分的 に存在しているが, 連続した線となっていないので図には 示されていない.与えられた $\varepsilon$ に対して実際に $a_{\mathrm{My}}, a_{\mathrm{Mp}}$ を選ぶときは $\mathrm{MD}=1 \mathrm{~m}$ の等高線に囲まれる中間の值を 選択すればよい，とを種々に変化させて各誘導法のシミュ レーションを行い, 弚の結果を第 12 図, 第 13 図に示した。 第 12 図は $\varepsilon$ とD の関係であり，第 13 図は $\varepsilon$ と次式で 与えられるような指令加速度の絶対値の積分值 $\Delta V$ の関係 である

$$
\Delta V=\int_{0}^{f}\left|F_{i \mathrm{c}}\right| \mathrm{d} t \quad(i=y, p)
$$

$\Delta V$ は lateral divert requirement ${ }^{1)}$ と呼ばれる量で誘導 に必要な全加速度量であり，これが大きいほど誘導抗力が 増加し速度低下を招くので小さい方が望ましい. 第 12 図 から $0 \sim 90^{\circ}$ のほぼ全オフボアサイト角に対して MD は， $\mathrm{MAPN}$ (実線) の場合 $2 \mathrm{~m}$ 以下となっているが, $\mathrm{PN}$ (点 


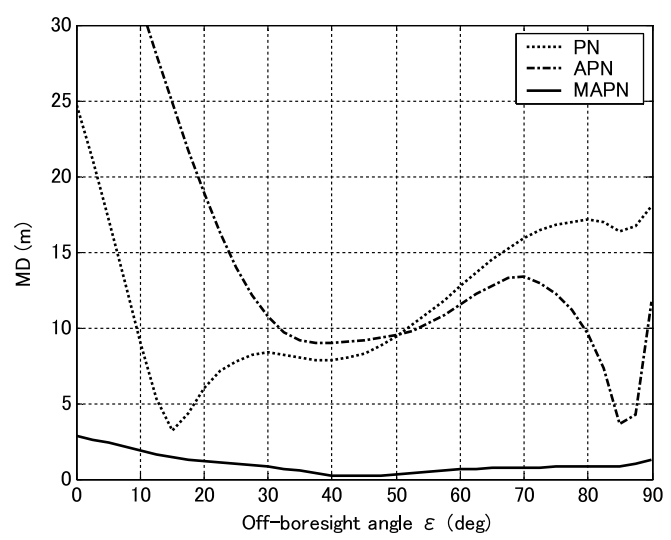

第 12 図 オフボアサイト角ごとのミスディスタンスの変化 $\left(R_{0}=\right.$ $1500 \mathrm{~m}, 3$ 次元)

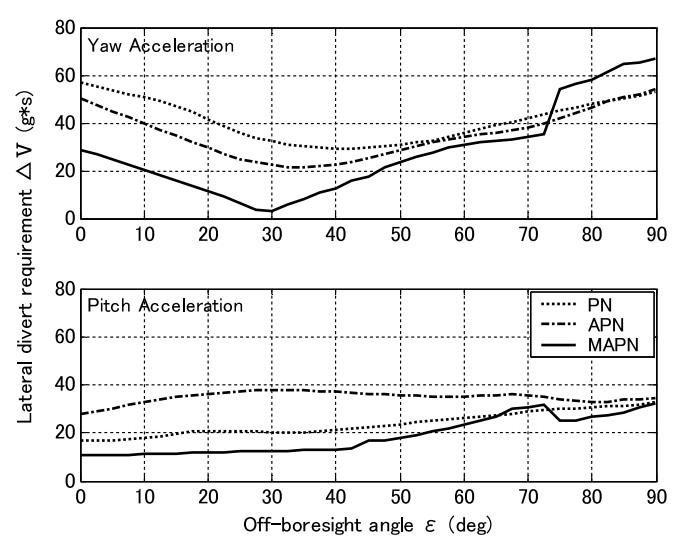

第13 図 オフボアサイト角ごとの飛翔体誘導加速度の絶対值の積分 値の変化 $\left(R_{0}=1500 \mathrm{~m}, 3\right.$ 次元 $)$
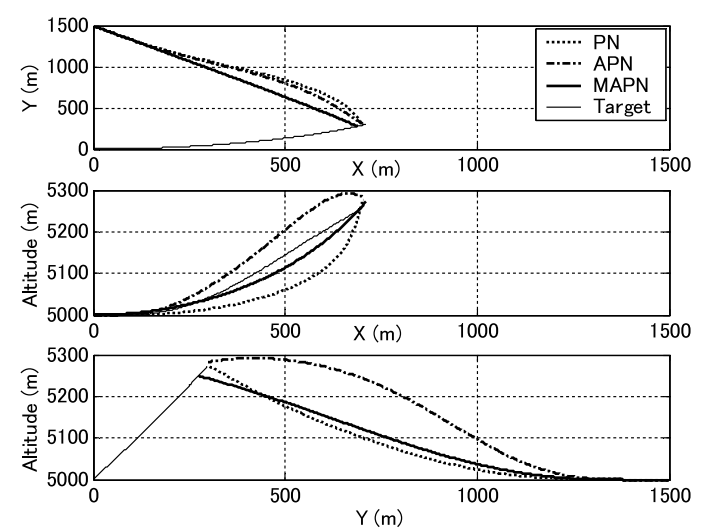

第 14 図 飛翔体と目標の軌跡 $\left(R_{0}=1500 \mathrm{~m}, \varepsilon=30^{\circ}, 3\right.$ 次元 $)$

線) と APN (一点鎖線) の場合 $7 \mathrm{~m}$ 以上になっているこ とがわかる.PNや APN では飛翔体は現在の速度を維持 し続けるものとして未来会合位置を予測し, 兴の点へ誘導 しているのてて飛翔体速度か変化すれば未来会合点も変化し， 弚れにつれて，飛翔体の軌道は左右に大きく曲げられるこ とになる．しかし，最終的に誘導システムの動的遅れがあ るために軌道修正が間に合わず大きなミスディスタンスを 生じることになる．また，PN と APN の $\Delta V$ は MAPN の $\Delta V$ より大きくなっていることが第 13 図から明らかで

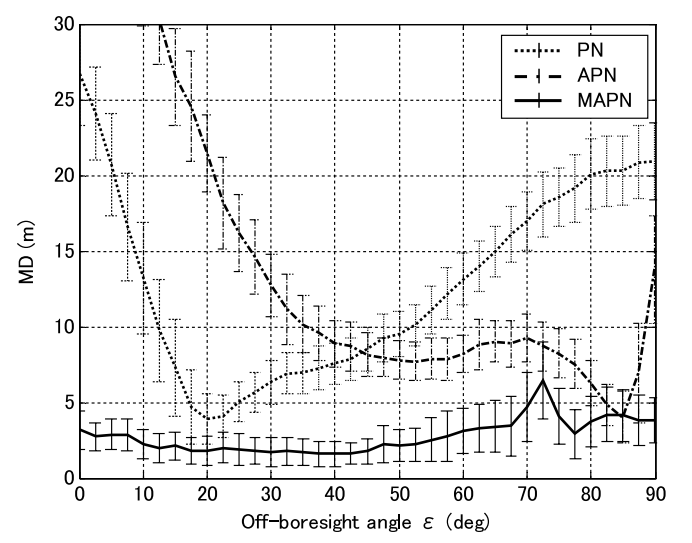

第15図 ノイズを加えたときのオフボアサイト角ごとのミスディスタ ンス (平均值と標準偏差) の変化 $\left(R_{0}=1500 \mathrm{~m}, 3\right.$ 次元 $)$

ある.このように MAPN は広いオフボアサイト角に対し て優れた誘導性能を持っているので, PNや APN に比べ て発射チャンスも増大することになる.第 14 図は $\varepsilon=30^{\circ}$ として発射したときの軌跡である.飛翔体は発射直後 0.5 秒のディスエイブル時間を持っているので, この期間中は 誘導法に関係なく発射方向へ直進しているが, 乥の後は各 誘導法によって軌跡は大きく異なっていることが第 14 図 からわかる、MAPN では, 設計パラメータを第 11 図から $a_{\mathrm{My}}=2, a_{\mathrm{Mp}}=4$ と選定したが, 兴の軌跡は会合点に向 かってほほ直線となっており, ミスディスタンスは $0.8 \mathrm{~m}$ と なった . PN は飛翔体の速度変化も目標の加速度情報も利用 していないので, 誘導が遅れていることか軌跡から明らか であり，ミスディスタンスは $8.4 \mathrm{~m}$ となった . 他方，APN では, 目標の加速度情報を利用しているので, ディスエイブ ル時間経過後, 直に予想会合点へ向かって大きく軌道変更 している.しかし, 最終的にはこの予想会合点か変化したた めに軌跡は前半とは逆方向へ大きく曲がっており，MD = $11.2 \mathrm{~m}$ となった .

最後に，修正改良型比例航法のノイズに対する有効性を 検討するためにLOS 角にノイズを加えてシミュレーショ ンを行った .ノイズはヨー方向の LOS 角 $\sigma_{\mathrm{y}}$ とピッチ方 向の LOS 角 $\sigma_{\mathrm{p}}$ の光れ艺れに第 2 図で示したような形で 2 種類のものを加えた . 1 つはパワースペクトル密度 $\Phi_{\mathrm{FN}}$ の白色ノイズを時定数 $\tau_{\mathrm{FN}}$ の成形フィルターに通したも のでフェーディングノイズを模擬している．もう1つはパ ワースペクトル密度 $\Phi_{\mathrm{GN}}$ の白色ノイズを時定数 $\tau_{\mathrm{GN}}$ の 成形フィルターに通し, かつ, 相対距離 $R$ の逆数をかけ たものでグリントノイズを模擬している.計算に使用した データは文献 7)，8）を参考にした .ノイズを加えたシミュ レーションはモンテカルロ法によって実施し, 各オフボア サイト角 $\left(2.5^{\circ}\right.$ 間融 $)$ にいて 100 回の計算を行い, 弚の ミスディスタンスの平均值と標準偏差を求めた . 飛翔体と 目標の初期条件は本節の 3 次元運動の場合と全く同じよう に設定した .計算結果を第 15 图に示す.この図をノイズ を含まない場合の結果である第 12 图と比較して次を得る. MAPN のノイズを含むときの MD は $\varepsilon$ が大きななるつ 
れて徐々に増大しているが, 弚の平均値は $4 \mathrm{~m}$ 以下となっ ている.また，標準偏差の分を考慮しても $65^{\circ}$ 以下の $\varepsilon に$ 対して $\mathrm{MD}$ は $5 \mathrm{~m}$ 以下となっている. 他方, APN につい ては， $45^{\circ} \leqq \varepsilon \leqq 85^{\circ}$ の間で，ノイズを含んだときの MD がノイズを含まないときの MD よりも小さくなっているが， 弚の他の $\varepsilon$ にいてはノイズの影響で $\mathrm{MD}$ は $1 \sim 4 \mathrm{~m}$ 程度 増大している．標準偏差の分を考慮すると，ほとんどすべ

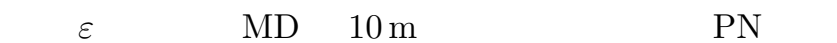
いても APN の場合と同樣, ノイズを含んだ MD がノイズ 無しのMD より小さくなるような $\varepsilon$ も存在するが，全体的 にはノイズの影響で $\mathrm{MD}$ は 1 〜 $\mathrm{m}$ 程度大きくなっており， 標準偏差の分を考慮するとほぼすべての $\varepsilon$ に対して $\mathrm{MD}$ は $8 \mathrm{~m}$ 以上となっている .

$$
\text { 5. あとがき }
$$

本論文ではブースト中またはバーンアウト後の光れ攵れ のフェーズにおいて, 速度变化する飛翔体が一定加速度で 回避運動する目標を追尾する問題を取り扱い，次の結論を 得た。

(i) 最終的に得られた誘導法は従来の改良型比例航法と単純 追尾航法を適当な比で合成したものであり，本論文では 便宜上, 修正改良型比例航法と呼んだ .

(ii) この修正改良型比例航法の実現には, 飛翔体情報及び目 標情報の測定及び推定が必要である．飛翔体情報はシー カー, 加速度計及びレートジャイロ等の搭載装置から, 目 標の相対位置と接近速度は発射母機あるいは飛翔体の搭 載レーダーから得られる.目標の速度や加速度は Kalman フィルタ等により推定することができる．

(iii) 修正改良型比例航法の誘導性能は合成比によって決ま るが，この合成比は飛翔体の減速度に相当する設計パラ メータを指定することによって一意的に決まる．

(iv) 設計パラメータは飛翔体の発射条件によって決まるの で, この誘導法を実際に利用するためには前もって種々 の発射条件について最適なパラメータを計算しておく必
要がある .

(v) 従来の改良型比例航法はバーンアウト後の減速度より ブースト中の加速度によって大きな影響を受けミスディ スタンスか増大する

（vi）スキッド・ツー・ターンする飛翔体の場合，修正改良 型比例航法はヨー面とピッチ面の各々について独立して 設計すれば良い .

(vii) 修正改良型比例航法では会合点に向かって直進するよ うな誘導を行っているので誘導に必要な全加速度量が小 さくなる．光のために改良型比例航法や比例航法に比べ て飛翔体の速度低下が小さい。

（viii）修正改良型比例航法は LOS 角にノイズを含まなけれ ば広いオフボアサイト角にわたってミスディスタンスを $2 \mathrm{~m}$ 以下とする .また , ノイズを含む場合でも数 $\mathrm{m}$ 以下 である。

\section{参 考 文 献}

1) Zarchan, P.: Tactical and Strategic Missile Guidance, Fourth ed., Progress in Astronautics and Aeronautics, Vol. 199, AIAA, Virginia, 2002, pp. 143-154.

2) Imado, F., Kuroda, T. and Ichikawa, A.: A Trade-Off Study between Conventional and Augmented Proportional Navigation, AIAA Paper 96-3882, 1996, pp. 1-8.

3) Shinar, J., Shima, T. and Kebke, A.: On the Validity of Linearized Analysis in the Interception of Reentry Vehicles, AIAA Paper 98-4303, 1998, pp. 1050-1060.

4) Shima, T. and Shinar, J.: Time-Varying Linear PursuitEvasion Game Models with Bounded Controls, J. Guid. Control Dynam., 25 (2002), pp. 425-432.

5）馬場順昭，高野博行：ブースト中の飛翔体の誘導法, 日本航空宇 宙学会論文集 , 48 (2000), pp. 385-391.

6）土肥直人, 馬場順昭, 高野博行 : ロケットモーター燃焼後の飛翔 体の誘導法一オフボアサイト能力の改善一, 日本航空宇宙学会論 文集， 51 (2003), pp. 380-387.

7) Lin, C.-F.: Modern Navigation, Guidance, and Control Processing, Prentice Hall Series in Advanced Navigation, Guidance, and Control, and Their Applications, Prentice Hall, Englewood Cliffs, N.J., 1991, pp. 45-48.

8) Miwa, S., Imado, F. and Kuroda, T.: Clutter Effect on the Miss Distance of a Radar Homing Missile, AIAA Paper 872449-CP, 1987, pp. 1-7. 